\author{
S.D. Fazylov ${ }^{1}$, O.A. Nurkenov ${ }^{1,4}$, A.Zh. Mukasheva ${ }^{1}$, \\ T.M. Seilkhanov ${ }^{2}$, Z.T. Shulgau ${ }^{3}$, A.M. Zhanzhuman ${ }^{4}$ \\ ${ }^{1}$ Institute of Organic Synthesis and Coal Chemistry of the Republic of Kazakhstan, Karaganda, Kazakhstan; \\ ${ }^{2}$ Sh. Ualikhanov Kokshetau State University, Kazakhstan; \\ ${ }^{3} R S E$ on the REM «National Center for Biotechnology» CS of the MES of the RK, Nur-Sultan, Kazakhstan; \\ ${ }^{4}$ Karaganda State Technical University, Kazakhstan \\ (E-mail: iosu8990@mail.ru)
}

\title{
Supramolecular inclusion complexes of functionally substituted N-benzylidene- and allylidene- isonicotinohydrazides with oligosaccharides and their properties
}

\begin{abstract}
This paper presents the results of a study of the synthesis and structural features of supramolecular inclusion complexes of N-benzylidene- and allylidene- isonicotinohydrazides with cyclic oligosaccharides (with $\beta$ - and 2 -hydroxypropyl- $\beta$-cyclodextrins). The results of studying the synthesis and structural features of supramolecular inclusion complexes of N-benzylidene and allylideneisonicotinohydrazides with cyclic oligosaccharides ( $\beta$ - and 2-hydroxypropyl- $\beta$-cyclodextrins) are presented. The structure of the obtained supramolecular inclusion complexes was studied using one-dimensional ${ }^{1} \mathrm{H},{ }^{13} \mathrm{C}$ and DEPT NMR and two-dimensional spectroscopy of COSY $\left({ }^{1} \mathrm{H}-{ }^{1} \mathrm{H}\right)$, HMQC $\left({ }^{1} \mathrm{H}^{-13} \mathrm{C}\right)$ and TOCSY $\left({ }^{1} \mathrm{H}^{-1} \mathrm{H}\right)$. The formation of supramolecular inclusion complexes was established on the basis of changes in the chemical shifts of the NMR of the substrate and receptor atoms. Based on the analysis of spectral data, the proposed schemes of the obtained supramolecular inclusion complexes are presented. It was found that the interaction of the studied hydrazone substrates with cyclodextrins forms inclusion complexes 1:1 and 1:2 with the entry of the substrate molecule into the internal cavity of the receptor. The resulting products are able to dissolve in water or form stable aqueous dispersions. The antiradical effect of the synthesized supramolecular inclusion complexes with respect to the 2,2-diphenyl-1-picrylhydrazide radical was evaluated. Under the conditions of this test system, antiradical activity was detected in the supramolecular complex of $\mathrm{N}$-(diethylamino)benzylidene-isonicotinohydrazide. The concentration of the complex was determined, capable of reducing the optical density of $100 \mu \mathrm{M}$ of the test system solution by $50 \%$.
\end{abstract}

Keywords: oligosaccharides, hydrazones, cyclodextrin, inclusion complexes, NMR spectroscopy, substrate.

\section{Introduction}

A well-known drawback of many modern drugs is the rapid decrease in their plasma levels after reaching peak metabolic destruction in the stomach of the body. This fact necessitates an increase in dose loads and, accordingly, increases the likelihood of side effects. In this regard, one of the most important attributes of drug delivery systems is the controlled release profile of the latter in the patient's body. Every year, many researchers find that biologically active substances cannot be obtained from clinical trials [1-3]. Therefore, one of the urgent tasks of modern pharmacological science is the targeted delivery of drug systems. Currently, biodegradable oligosaccharides (cyclodextrins) have been used to transport drugs [4-6]. Cyclodextrins (CDs) are complex natural cyclic oligosaccharides consisting of D-glucopyranose residues connected by an $\alpha-1,4-$ glycosidic bond. On the basis of wide distribution and commercial use, $\alpha$-, $\beta$ - and $\gamma$-cyclodextrins were obtained, the macro rings of which consist of 6,7 and 8 residues of D-glucose, respectively. They are unique natural nanostructures equipped with a hydrophobic internal cavity and a hydrophilic external surface. They are able to form various forms: micelles, vesicles and more complex forms. The formation of all these complex forms is governed by a hydrophobic effect.

These are «molecular containers» that are capable of holding non-polar, non-ionized molecules of the «guest» substance in the internal cavity. This leads to the formation of complexes, which include a hydrophobic molecule of the «guest» substance, a unique property to dissolve in the aqueous phase due to the hydrophilic outer surface of the molecular container [7-12]. Molecules of cyclodextrins contain both polar and non-polar parts. They form very complex structures: micelles, vesicles, layers and more complex forms. The formation of all these complex forms is governed by the hydrophobic effect [8-11].

The most common type of complex includes cyclodextrin and the drug/cyclodextrin (D/CD) complex in a 1:2-1 ratio, which contains one drug (D), which forms a complex with one cyclodextrin (CD) molecule [1315]: 


$$
\mathrm{D}+\mathrm{CD} \stackrel{K_{1: 1} \rightleftharpoons}{\rightleftharpoons} \mathrm{D} / \mathrm{CD}
$$

Cyclodextrins can form higher-order drug / cyclodextrin complexes, depending on the nature and structure of the ligand-substrate, in a 1:2 ratio:

$$
\mathrm{D} / \mathrm{CD}+\mathrm{CD} \stackrel{K_{1: 2}}{\rightleftharpoons} \mathrm{D} / \mathrm{CD}_{2}
$$

Currently, CDs are widely used in the food, cosmetic, pharmaceutical industries, in analytical chemistry, and in protecting the environment from ecotoxicants and others [9-12]. Further prospects for the use of diabetes in pharmacology and medicine are associated with the development of so-called targeted drugs for antitumor and gene therapy [16-19]. If the receptor acts as a target, then the bioactive drug will be a ligand with respect to it, i.e. a compound specifically interacting with the active center of the receptor. The formation of such a supramolecular complex causes high selectivity and lower toxicity of the drugs. In this regard, in recent years, CDs and their derivatives have been actively used for targeted drug delivery in the form of a molecular container. Such encapsulation protects the «guest» molecule from damage by various reactive molecules and thereby reduces the rate of oxidation, steric rearrangements, hydrolysis, racemization and enzymatic degradation, as well as enhances its water solubility and, as a result, a more effective pharmacological effect.

For analysis of supramolecular inclusion complexes, the methods of proton magnetic resonance spectroscopy on ${ }^{1} \mathrm{H}$ nuclei and nuclear magnetic resonance spectroscopy on ${ }^{13} \mathrm{C}$ nuclei are mainly used. The most informative method for confirming the formation of inclusion complexes is ${ }^{1} \mathrm{H}$ NMR spectroscopy [13-15, 20-24]. This analysis method allows one to fix a pronounced chemical shift in the vibrational spectra of $\mathrm{H} 3$, $\mathrm{H} 5 \beta$-CD protons oriented inside the torus cavity, which is due to the placement of the «guest» substance molecule in the hydrophobic cyclodextrin cavity. In this case, insignificant chemical shifts are observed in the vibrational spectra of the $\mathrm{H} 1, \mathrm{H} 2$, and $\mathrm{H} 4$ atoms localized on the outer surface of the molecule.

The ${ }^{13} \mathrm{C}-\mathrm{NMR}$ spectroscopy method allows one to detect chemical shifts in the electronic environment of carbon atoms of the cavity of a cyclodextrin molecule resulting from the van der Waals and electrostatic interaction of the molecules of the «guest» substance with the molecules of the host substance [13-15]. With an increase in the concentration of the «guest» substance in the system, a proportional increase in the chemical shift in the vibrational spectra is observed, due to a shift in the equilibrium state towards the formation of inclusion complexes [19-28].

\section{Experimental}

$\alpha$-, $\beta$-, $\gamma$ - and 2-Hydroxypropyl- $\beta$-cyclodextrins were used by Fluka, $99 \%$ pure. The ${ }^{1} \mathrm{H}$ and ${ }^{13} \mathrm{C}$ NMR spectra of the compounds were recorded on a Jeol JNM-ECA 400 spectrometer $(399.78$ and $100.53 \mathrm{MHz}$ on ${ }^{1} \mathrm{H}$ and ${ }^{13} \mathrm{C}$ nuclei, respectively) in a DMSO- $\mathrm{d}_{6}$ solution at room temperature. Chemical shifts are measured relative to the residual signals of protons or carbon atoms of DMSO- $\mathrm{d}_{6}$.

In this work, we selected spectroscopic methods to study supramolecular complexes for the inclusion of functionally substituted isonicotinic acid hydrazone with cyclodextrins ( $\beta-\mathrm{CD}, 2$-hydroxypropyl- $\beta-\mathrm{CD})$. Hydrazones - N-(diethylamino)benzylidene isonicotinohydrazide (1), N-(2-bromo-3-phenyl)allylidenisonicotinohydrazide (2) and N'-((5-nitrofuran-2-yl) methylene) was chosen as hydrazone substrates isonicotinohydrazide (3). The procedures for the preparation of inclusion complexes of functionally substituted N-benzylidene- and allylidene- isonicotinohydrazide (1-3) with $\beta$ - and hydroxypropyl- $\beta$-cyclodextrins were described by us in [29-31].

Preliminary bioprognosis (1-3) using the PASS program showed high rates of their manifestation of antituberculosis, antimycobacterial, antioxidant activity and inhibitors of glutaminophenylpurivate transaminase and threonine aldolase. The above compounds (1-3) are characterized by their poor solubility in water. The inclusion of substrates (1-3) in the cavity of the host molecule will increase the solubility of the substance, improve bioavailability and contribute to obtaining more in-depth data on their biological properties.<smiles>CCN(CC)c1ccc(/C=N/NC(=O)c2ccncc2)cc1</smiles> 


\section{Results and Discussion}

The NMR spectroscopic study of supramolecular inclusion complexes (4-6), obtained on the basis of functionally substituted hydrazone (1-3) of isonicotinic acid and cyclodextrins, is based on determining the difference in the values of chemical shifts ${ }^{1} \mathrm{H}$ and ${ }^{13} \mathrm{C}$ of substrates and receptor $(\alpha-, \beta-, \gamma-\mathrm{CD})$ in the free state and in the composition of complexes as a result of intermolecular interaction.

The NMR spectrum of an individual $\beta$-CD (Fig. 1) is characterized by the manifestation of six groups of signals in the region $3.23-3.32 ; 3.45-3.60 ; 4.47-4.49 ; 4.77-4.78 ; 5.66 ; 5.71-5.73 \mathrm{ppm}$.

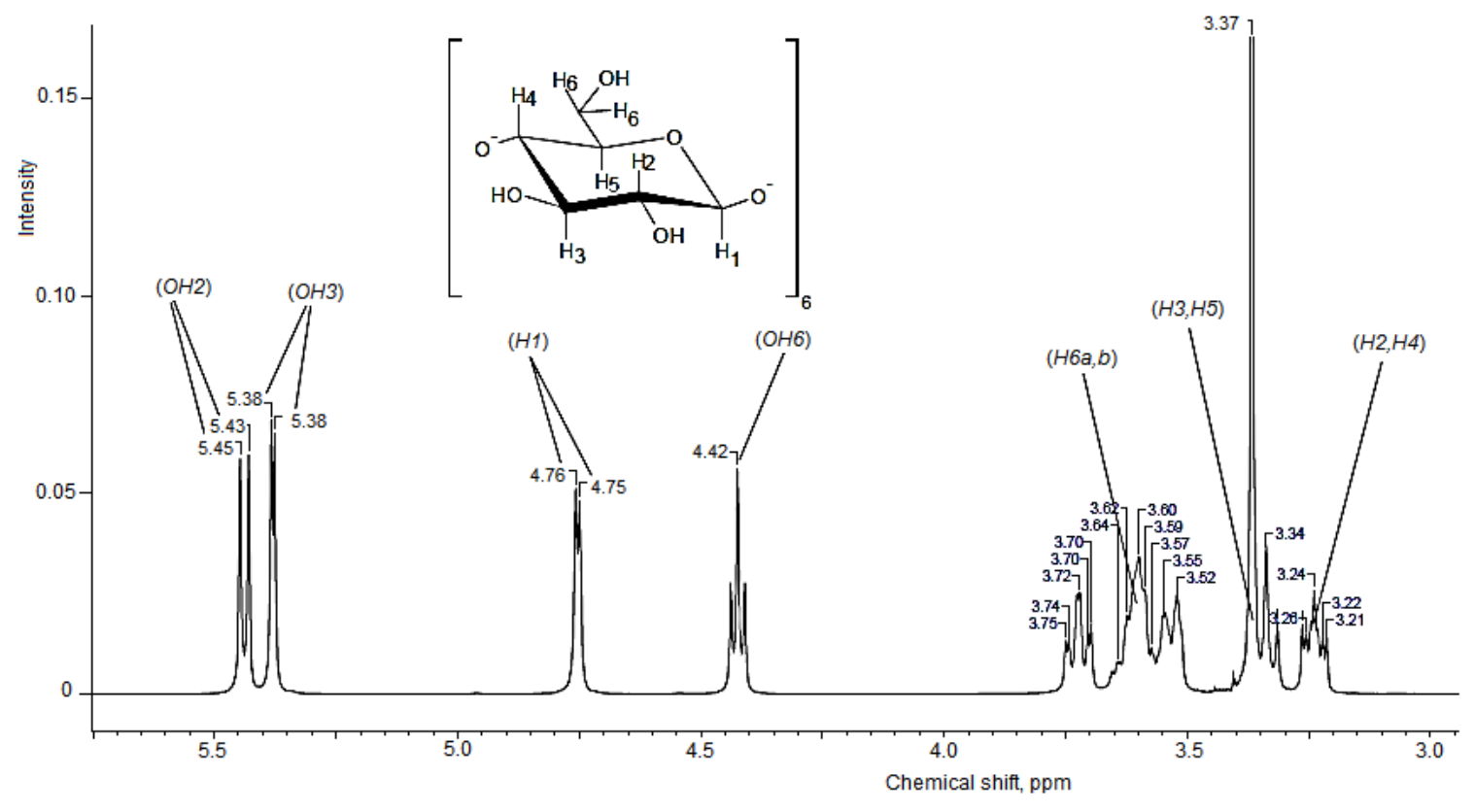

Figure 1. ${ }^{1} \mathrm{H}$ NMR spectrum of $\beta-\mathrm{CD}$

Doublet signal in the range 5.71-5.73 ppm with a splitting of $4 \mathrm{~Hz}$, it belongs to the proton of the hydroxyl group at the $\mathrm{C}-2$ atom. The proton of the $\mathrm{OH}$ group of a neighboring atom $(\mathrm{OH}-3)$ located in the internal cavity of the $\beta$-CD molecule ( $\delta=5.66 \mathrm{ppm}$, doublet) also resonates in the low-field region. Doublet signal in the region of 4.77-4.78 ppm corresponds to the proton $\mathrm{H}-1 \beta-\mathrm{CD}$. The location of this proton in a weaker field compared to the protons of other $\mathrm{CH}$ groups is due to the influence of the oxygen atom. The hydroxyl group OH- 6 resonates, splitting into a triplet with a center at $4.48 \mathrm{ppm}$. In the region of a strong field at $3.49-3.60 \mathrm{ppm}$ signals of protons H-6a, $b$ of the methylene group are observed. High-intensity signal at $3.45 \mathrm{ppm}$ corresponds to the protons $\mathrm{H}-3$ and $\mathrm{H}-5$ of the glucopyranose link. In the range from 3.23 to $3.32 \mathrm{ppm}$. methine protons $\mathrm{H}-$ 2 and $\mathrm{H}-4$ are manifested $[8,11,23,29,30]$.

The carbon NMR spectrum of $\beta$-CD (Fig. 2) represents six signals of ${ }^{13} \mathrm{C}$ nuclei of the elementary unit. In the strong-field part, the signal of the C-6 carbon atom appears at $60.41 \mathrm{ppm}$. Signals at $72.49,72.85$ and $7351 \mathrm{ppm}$ are caused by C-5, C-2 and C-3 atoms, respectively. In the region of a weaker field at 82.02 and 102.41 ppm signals of carbon atoms C-4 and C-1 are observed, respectively, directly connected to the adjacent glucopyranose link through the oxygen bridge.

Studying the one-dimensional spectra of $\beta$-CD in the free and bound state) reveals the pattern of displacement of all ${ }^{1} \mathrm{H}$ and ${ }^{13} \mathrm{C}$ signals of the host molecule to the weak field region, which confirms the non-valent binding with the guest.

For proton spectra, the largest difference in the values of the chemical shift $(\Delta \delta=+0.10 \mathrm{ppm})$ is characteristic of the intraspheric protons $\mathrm{N}-3$ and $\mathrm{N}-5$, on the basis of which it can be concluded that an internal (inclusion) complex with a substrate is formed. In the case of the carbon spectrum, the difference is more significant and ranges from $0.05-0.25 \mathrm{ppm}$. Thus, the formation of supramolecular inclusion complexes is established on the basis of changes in the NMR chemical shifts of the substrate and receptor atoms [28-33]. 


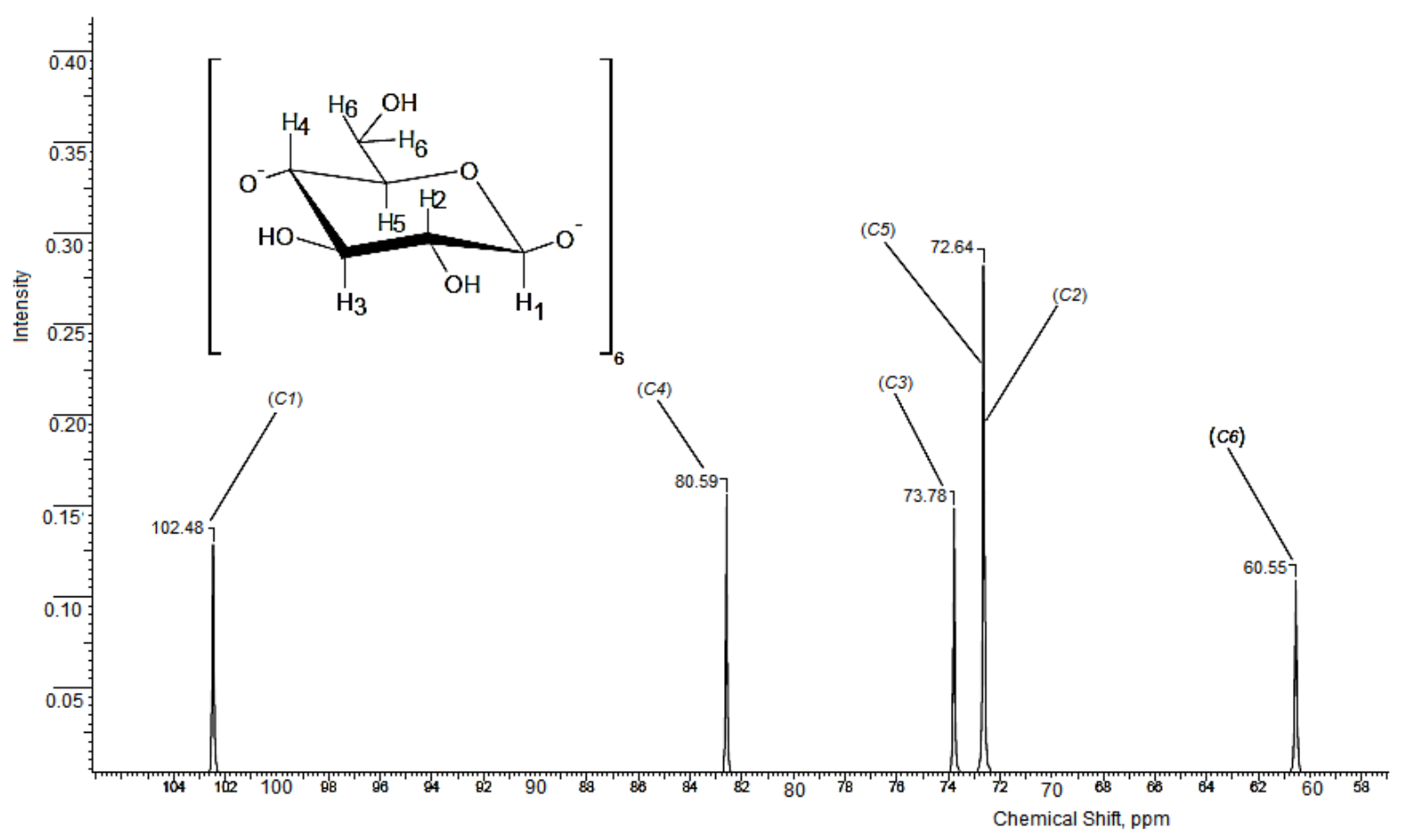

Figure 2. ${ }^{13} \mathrm{C}$ NMR spectrum of $\beta$-CD

The study by NMR spectroscopy of supramolecular complexes is based on determining the difference in the chemical shifts of ${ }^{1} \mathrm{H}$ and ${ }^{13} \mathrm{C}$ of substrates $(12-14)$ and receptors $(\beta-\mathrm{CD}$, 2-hydroxypropyl - $\beta$-CD) in the free state and in the composition of the complexes as a result of intermolecular interaction. By the magnitude of the chemical shifts of the internal or external protons of the receptor, it is possible to reveal the formation of internal (inclusion) or external (without inclusion) complexes, respectively. A change in the chemical shifts of ${ }^{1} \mathrm{H}$ and ${ }^{13} \mathrm{C}$ in the spectra of the substrates allows us to determine the direction of their entry into the cavity of $\mathrm{CD}$.

The structure of substrates for supramolecular self-assembly (1) and (2) was established based on the results of ${ }^{1} \mathrm{H}$ and ${ }^{13} \mathrm{C}$ NMR spectroscopy obtained in DMSO- $\mathrm{d}_{6}$ (Table 1, 2 (1) and 1, 3, 4 (2). One-dimensional ${ }^{1} \mathrm{H}$ and ${ }^{13} \mathrm{C}$ NMR spectra (1) and (2) was confirmed by two-dimensional correlation data of ${ }^{1} \mathrm{H}-{ }^{1} \mathrm{H}$ COSY, ${ }^{1} \mathrm{H}-$ ${ }^{13} \mathrm{C}$ HMQC NMR spectra (Table 1).

$\mathrm{Tab} l \mathrm{e} 1$

${ }^{1} \mathrm{H},{ }^{13} \mathrm{C},{ }^{1} \mathrm{H}-{ }^{1} \mathrm{H}$ COSY NMR spectroscopy data, ${ }^{1} \mathrm{H}-{ }^{13} \mathrm{C}$ HMQC substrates (1) and (2)

\begin{tabular}{|c|c|c|c|c|}
\hline \multirow{2}{*}{$\begin{array}{l}\text { Sub- } \\
\text { strate }\end{array}$} & \multicolumn{4}{|c|}{$\delta$, ppm, J, Hz } \\
\hline & ${ }^{1} \mathrm{H}$ & ${ }^{13} \mathrm{C}$ & ${ }^{1} \mathrm{H}-{ }^{1} \mathrm{H} \mathrm{COSY}$ & ${ }^{1} \mathrm{H}-{ }^{13} \mathrm{C}$ HMQC \\
\hline 1 & 2 & 3 & 4 & 5 \\
\hline 1 & $\begin{array}{c}1.06 \mathrm{t}\left(6 \mathrm{H}, \mathrm{H}-20,22,{ }^{3} \mathrm{~J} 6.9\right), \\
3.31-3.35 \mathrm{~m}(4 \mathrm{H}, \mathrm{H}-19,21), \\
6.66 \mathrm{~d}\left(2 \mathrm{H}, \mathrm{H}-14,16,{ }^{3} \mathrm{~J} 8.7\right), \\
7.48 \mathrm{~d}\left(2 \mathrm{H}, \mathrm{H}-13,17,{ }^{3} \mathrm{~J} 8.7\right), \\
7.77 \mathrm{~d}\left(2 \mathrm{H}, \mathrm{H}-3,5,{ }^{3} \mathrm{~J} 4.6\right), \\
8.25 \mathrm{~s}(1 \mathrm{H}, \mathrm{H}-23), 8.72 \mathrm{~d}(2 \mathrm{H}, \\
\left.\mathrm{H}-2,6,{ }^{3} \mathrm{~J} 4.6\right), 11.72 \mathrm{~s}(1 \mathrm{H}, \mathrm{H}-9)\end{array}$ & $\begin{array}{c}12.96(\mathrm{C}-20,23), 44.26 \\
(\mathrm{C}-19,21), 111.56(\mathrm{C}-14,16) \\
120.76(\mathrm{C}-12), 122.00 \\
(\mathrm{C}-3,5), 129.56(\mathrm{C}-13,17) \\
141.37(\mathrm{C}-4,11), 149.57 \\
(\mathrm{C}-2,6), 150.41(\mathrm{C}-15) \\
161.48(\mathrm{C}-7)\end{array}$ & \begin{tabular}{|}
$\mathrm{H}^{19,21}-\mathrm{H}^{20,22}(1.03$ \\
$3.33 ; 3.32,1.05)$ \\
$\mathrm{H}^{13,17}-\mathrm{H}^{14,16}(6.65$ \\
$7.48 ; 7.48,6,66)$ \\
$\mathrm{H}^{3,5}-\mathrm{H}^{2,6}(7.76,8.72$ \\
$8.71,7.77)$
\end{tabular} & $\begin{array}{c}\mathrm{H}^{20,22}-\mathrm{C}^{20,22}(1.03, \\
12.93) ; \mathrm{H}^{14,16}-\mathrm{C}^{14,16} \\
(6.63,111.53) ; \\
\mathrm{H}^{13,17}-\mathrm{C}^{13,17}(7.45, \\
129.54) ; \mathrm{H}^{3,5}-\mathrm{C}^{3,5}(7.76, \\
121.92) ; \mathrm{H}^{2,6}-\mathrm{C}^{2,6}(8.70, \\
150.73)\end{array}$ \\
\hline 2 & $\begin{array}{c}\text { 7.38-7.43 m (3H, H-15,19,17), } \\
7.67 \text { s }(1 \mathrm{H}, \mathrm{H}-13), 7.77 \mathrm{~d}(2 \mathrm{H}, \mathrm{H}- \\
\left.3,5,{ }^{3} \mathrm{~J} 1.8\right), 7.84 \mathrm{~d}(2 \mathrm{H}, \mathrm{H}-16,18, \\
\left.{ }^{3} \mathrm{~J} 6.4\right), 8.34 \mathrm{~s}(1 \mathrm{H}, \mathrm{H}-11), 8.75 \mathrm{~d} \\
(2 \mathrm{H}, \mathrm{H}-2,6), 12.19 \mathrm{~s}(1 \mathrm{H}, \mathrm{H}-9)\end{array}$ & \begin{tabular}{|c|}
$119.50(\mathrm{C}-12), 122.07$ \\
$(\mathrm{C}-3,5), 128.99(\mathrm{C}-15,19)$ \\
$130.01(\mathrm{C}-17), 130.34$ \\
$(\mathrm{C}-16,18), 135.04(\mathrm{C}-14)$ \\
$139.37(\mathrm{C}-13), 140.85(\mathrm{C}-4)$, \\
$149.53(\mathrm{C}-11), 150.90(\mathrm{C}-$ \\
$2,6), 162.27(\mathrm{C}-7)$
\end{tabular} & $\begin{array}{c}\mathrm{H}^{16,18}-\mathrm{H}^{15,17,19}(7.40 \\
7.84 ; 7.83,7.43) \\
\mathrm{H}^{2,6}-\mathrm{H}^{3,5}(7.76,8.75 \\
8.74,7.77)\end{array}$ & $\begin{array}{c}\mathrm{H}^{15,19}-\mathrm{C}^{15,19}(7.40 \\
129.31) ; \mathrm{H}^{13}-\mathrm{C}^{13}(7.67 \\
139.39) ; \mathrm{H}^{3,5}-\mathrm{C}^{3,5}(7.76 \\
122.07) ; \mathrm{H}^{16,18}-\mathrm{C}^{16,18} \\
(7.85,130.14) ; \mathrm{H}^{11}-\mathrm{C}^{11} \\
(8.32,119.49) ; \mathrm{H}^{2,6}-\mathrm{C}^{2,6} \\
(8.74,150.97)\end{array}$ \\
\hline
\end{tabular}


The ratio of the integral intensities of protons in the compounds under consideration corresponded to the presented structures (1) and (2).

${ }^{1} \mathrm{H}$ and ${ }^{13} \mathrm{C}$ NMR spectra of $\beta$ - and 2-hydroxypropyl- $\beta$-CD in the free state and supramolecular complexes (4-6) based on them with substrates (1) and (2) are presented in Tables 2-4.

Chemical shifts of ${ }^{1} \mathrm{H}$ and ${ }^{13} \mathrm{C}$ nuclei of the substrate (1) and 2- hydroxypropyl- $\beta$-cyclodextrinin the free state $\left(\delta_{0}\right)$ and in the complex $(4)(\delta)$

\begin{tabular}{|c|c|c|c|c|c|c|c|}
\hline \multirow{2}{*}{$\begin{array}{c}\text { Atom } \\
\text { number }\end{array}$} & \multirow{2}{*}{ Group } & \multicolumn{2}{|c|}{$\delta_{0}, \mathrm{ppm}$} & \multicolumn{2}{|c|}{$\delta, \mathrm{ppm}$} & \multicolumn{2}{|c|}{$\Delta \delta=\delta-\delta_{0}$} \\
\hline & & ${ }^{1} \mathrm{H}$ & ${ }^{13} \mathrm{C}$ & ${ }^{1} \mathrm{H}$ & ${ }^{13} \mathrm{C}$ & ${ }^{1} \mathrm{H}$ & ${ }^{13} \mathrm{C}$ \\
\hline \multicolumn{8}{|c|}{ Substrate (1) } \\
\hline 2 & $\mathrm{CH}$ & 8.72 & 149.57 & 8.71 & 150.75 & -0.01 & 1.18 \\
\hline 3 & $\mathrm{CH}$ & 7.77 & 122.00 & 7.76 & 121.99 & -0.01 & -0.01 \\
\hline 4 & $\mathrm{C}$ & & 141.37 & & 141.69 & & 0.32 \\
\hline 5 & $\mathrm{CH}$ & 7.77 & 122.00 & 7.76 & 121.99 & -0.01 & -0.01 \\
\hline 6 & $\mathrm{CH}$ & 8.72 & 149.57 & 8.71 & 150.75 & -0.01 & 1.18 \\
\hline 7 & $\mathrm{C}$ & & 161.48 & & 163.82 & & 2.34 \\
\hline 9 & $\mathrm{NH}$ & 11.72 & & 11.63 & & -0.11 & \\
\hline 11 & $\mathrm{CH}$ & & 141.37 & & 141.69 & & 0.32 \\
\hline 12 & $\mathrm{C}$ & & 120.76 & & 120.94 & & 0.18 \\
\hline 13 & $\mathrm{CH}$ & 7.48 & 129.56 & 7.48 & 129.55 & 0 & -0.01 \\
\hline 14 & $\mathrm{CH}$ & 6.66 & 111.56 & 6.68 & 111.60 & 0.02 & 0.04 \\
\hline 15 & $\mathrm{C}$ & & 150.41 & & 151.53 & & 1.12 \\
\hline 16 & $\mathrm{CH}$ & 6.66 & 111.56 & 6.68 & 111.60 & 0.02 & 0.04 \\
\hline 17 & $\mathrm{CH}$ & 7.48 & 129.56 & 7.48 & 129.55 & 0 & -0.01 \\
\hline 19 & $\mathrm{CH}_{2}$ & 3.35 & 44.26 & 3.36 & 44.27 & 0.01 & 0.01 \\
\hline 20 & $\mathrm{CH}_{3}$ & 1.06 & 12.96 & 1.00 & 12.84 & -0.06 & -0.12 \\
\hline 21 & $\mathrm{CH}_{2}$ & 3.35 & 44.26 & 3.36 & 44.27 & 0.01 & 0.01 \\
\hline 22 & $\mathrm{CH}_{3}$ & 1.06 & 12.96 & 1.00 & 12.84 & -0.06 & -0.12 \\
\hline 23 & $\mathrm{CH}$ & 8.25 & & 8.26 & & 0.01 & \\
\hline \multicolumn{8}{|c|}{$2-\mathrm{HP}-\beta-\mathrm{CD}$} \\
\hline 1 & $\mathrm{CH}$ & 4.79 & 102.33 & 4.80 & 102.29 & 0.01 & -0.04 \\
\hline 2 & $\mathrm{CH}$ & 3.26 & 72.56 & 3.28 & 72.94 & 0.02 & 0.38 \\
\hline 3 & $\mathrm{CH}$ & 3.70 & 73.56 & 3.73 & 73.55 & 0.03 & -0.01 \\
\hline 4 & $\mathrm{CH}$ & 3.18 & 82.11 & 3.21 & 82.20 & 0.03 & 0.09 \\
\hline 5 & $\mathrm{CH}$ & 3.56 & 72.56 & 3.60 & 72.30 & 0.04 & -0.26 \\
\hline 6 & $\mathrm{CH}_{2}$ & 3.56 & 60.40 & 3.60 & 60.43 & 0.04 & 0.03 \\
\hline
\end{tabular}

Chemical shifts of ${ }^{1} \mathrm{H}$ and ${ }^{13} \mathrm{C}$ nuclei of the substrate (2)

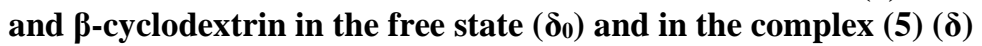

\begin{tabular}{|c|c|c|c|c|c|c|c|}
\hline \multirow{2}{*}{$\begin{array}{l}\text { Atom } \\
\text { number }\end{array}$} & \multirow{2}{*}{ Group } & \multicolumn{2}{|c|}{$\delta_{0}, \mathrm{ppm}$} & \multicolumn{2}{|c|}{$\delta, \mathrm{ppm}$} & \multicolumn{2}{|c|}{$\Delta \delta=\delta-\delta_{0}$} \\
\hline & & ${ }^{1} \mathrm{H}$ & ${ }^{13} \mathrm{C}$ & ${ }^{1} \mathrm{H}$ & ${ }^{13} \mathrm{C}$ & ${ }^{1} \mathrm{H}$ & ${ }^{13} \mathrm{C}$ \\
\hline 1 & 2 & 3 & 4 & 5 & 6 & 7 & 8 \\
\hline \multicolumn{8}{|c|}{ Substrate (2) } \\
\hline 2 & $\mathrm{CH}$ & 8.75 & 150.90 & 8.38 & 150.98 & -0.37 & 0.08 \\
\hline 3 & $\mathrm{CH}$ & 7.77 & 122.07 & 7.95 & 124.49 & 0.18 & 2.42 \\
\hline 4 & $\mathrm{C}$ & & 140.85 & & & & \\
\hline 5 & $\mathrm{CH}$ & 7.77 & 122.07 & 7.95 & 124.49 & 0.18 & 2.42 \\
\hline 6 & $\mathrm{CH}$ & 8.75 & 150.98 & 8.38 & 150.98 & -0.37 & 0.08 \\
\hline 7 & $\mathrm{C}$ & & 162.27 & & & & \\
\hline 9 & $\mathrm{NH}$ & 12.19 & & 12.19 & & 0 & \\
\hline 11 & $\mathrm{CH}_{\mathrm{a}}$ & 8.34 & 149.53 & 8.38 & & 0.04 & \\
\hline 12 & $\mathrm{C}$ & & 119.50 & & & & \\
\hline 13 & $\mathrm{CH}_{\mathrm{a}}$ & 7.67 & 139.37 & 7.95 & & 0.28 & \\
\hline
\end{tabular}


Supramolecular inclusion complexes of functionally substituted ...

Continuation of Table 3

\begin{tabular}{|c|c|c|c|c|c|c|c|}
\hline 1 & 2 & 3 & 4 & 5 & 6 & 7 & 8 \\
\hline 14 & $\mathrm{C}$ & 7.43 & 135.04 & & 133.50 & & -1.54 \\
\hline 15 & $\mathrm{CH}$ & 128.99 & 7.53 & 129.42 & 0.10 & 0.43 \\
\hline 16 & $\mathrm{CH}$ & 7.84 & 130.34 & 7.95 & 131.17 & 0.11 & 0.83 \\
\hline 17 & $\mathrm{CH}$ & 7.43 & 130.01 & 7.53 & 132.11 & 0.10 & 2.10 \\
\hline 18 & $\mathrm{CH}$ & 7.84 & 130.34 & 7.95 & 131.17 & 0.11 & 0.83 \\
\hline 19 & $\mathrm{CH}$ & 7.43 & 128.99 & 7.53 & 129.42 & 0.10 & 0.43 \\
\hline \multicolumn{7}{|l|}{$\beta-\mathrm{CD}$} \\
\hline 1 & $\mathrm{CH}$ & 4.77 & 102.40 & 4.79 & 102.46 & 0.02 & 0.06 \\
\hline 2 & $\mathrm{CH}$ & 3.26 & 72.83 & 3.27 & 72.93 & 0.01 & 0.10 \\
\hline 3 & $\mathrm{CH}$ & 3.58 & 73.54 & 3.60 & 73.57 & 0.02 & 0.03 \\
\hline 4 & $\mathrm{CH}$ & 3.28 & 81.98 & 3.31 & 82.07 & 0.03 & 0.09 \\
\hline 5 & $\mathrm{CH}$ & 3.50 & 72.50 & 3.51 & 72.56 & 0.01 & 0.06 \\
\hline 6 & $\mathrm{CH}$ & 3.58 & 60.42 & 3.60 & 60.45 & 0.02 & 0.03 \\
\hline
\end{tabular}

Table 4

Chemical shifts of ${ }^{1} \mathrm{H}$ and ${ }^{13} \mathrm{C}$ nuclei of the substrate (2) and 2- hydroxypropyl- $\beta$-cyclodextrin in the free state $\left(\delta_{0}\right)$ and in the complex $(6)(\delta)$

\begin{tabular}{|c|c|c|c|c|c|c|c|}
\hline \multirow{2}{*}{$\begin{array}{c}\text { Atom } \\
\text { number }\end{array}$} & \multirow[t]{2}{*}{ Group } & \multicolumn{2}{|c|}{$\delta_{0}, \mathrm{ppm}$} & \multicolumn{2}{|c|}{$\delta, \mathrm{ppm}$} & \multicolumn{2}{|c|}{$\Delta \delta=\delta-\delta_{0}$} \\
\hline & & ${ }^{1} \mathrm{H}$ & ${ }^{13} \mathrm{C}$ & ${ }^{1} \mathrm{H}$ & ${ }^{13} \mathrm{C}$ & ${ }^{1} \mathrm{H}$ & ${ }^{13} \mathrm{C}$ \\
\hline \multicolumn{8}{|c|}{ Substrate (2) } \\
\hline 2 & $\mathrm{CH}$ & 8.75 & 150.90 & 8.78 & 149.72 & 0.03 & -1.82 \\
\hline 3 & $\mathrm{CH}$ & 7.77 & 122.07 & 7.87 & 124.04 & 0.10 & 1.97 \\
\hline 4 & $\mathrm{C}$ & & 140.85 & & 140.25 & & -0.60 \\
\hline 5 & $\mathrm{CH}$ & 7.77 & 122.07 & 7.87 & 124.04 & 0.10 & 1.97 \\
\hline 6 & $\mathrm{CH}$ & 8.75 & 150.98 & 8.78 & 149.72 & 0.03 & -1.82 \\
\hline 7 & $\mathrm{C}$ & & 162.27 & & 163.61 & & 1.34 \\
\hline 9 & $\mathrm{NH}$ & 12.19 & & 12.19 & & 0 & \\
\hline 11 & $\mathrm{CH}_{\mathrm{a}}$ & 8.34 & 149.53 & 8.38 & 149.72 & 0.04 & 0.19 \\
\hline 12 & $\mathrm{C}$ & & 119.50 & & & & \\
\hline 13 & $\mathrm{CH}_{\mathrm{a}}$ & 7.67 & 139.37 & 7.87 & 139.64 & 0.20 & 0.27 \\
\hline 14 & $\mathrm{C}$ & & 135.04 & & 131.18 & & -3.86 \\
\hline 15 & $\mathrm{CH}$ & 7.43 & 128.99 & 7.52 & 129.00 & 0.09 & 0.01 \\
\hline 16 & $\mathrm{CH}$ & 7.84 & 130.34 & 7.87 & 129.42 & 0.03 & -0.62 \\
\hline 17 & $\mathrm{CH}$ & 7.43 & 130.01 & 7.52 & 129.42 & 0.09 & -0.59 \\
\hline 18 & $\mathrm{CH}$ & 7.84 & 130.34 & 7.87 & 129.42 & 0.03 & -0.62 \\
\hline 19 & $\mathrm{CH}$ & 7.43 & 128.99 & 7.52 & 129.00 & 0.09 & 0.01 \\
\hline \multicolumn{8}{|c|}{$2-\mathrm{HP}-\beta-\mathrm{CD}$} \\
\hline 1 & $\mathrm{CH}$ & 4.79 & 102.33 & 4.80 & 102.36 & 0.01 & 0.03 \\
\hline 2 & $\mathrm{CH}$ & 3.26 & 72.56 & 3.28 & 72.91 & 0.02 & 0.35 \\
\hline 3 & $\mathrm{CH}$ & 3.70 & 73.56 & 3.73 & 73.53 & 0.03 & -0.03 \\
\hline 4 & $\mathrm{CH}$ & 3.18 & 82.11 & 3.21 & 82.01 & 0.03 & -0.10 \\
\hline 5 & $\mathrm{CH}$ & 3.56 & 72.56 & 3.60 & 72.91 & 0.04 & 0.35 \\
\hline 6 & $\mathrm{CH}_{2}$ & 3.56 & 60.40 & 3.60 & 60.66 & 0.04 & 0.20 \\
\hline
\end{tabular}

Comparison of the integral intensities of ${ }^{1} \mathrm{H}$ NMR signals of substrate molecules (1 and 2) and receptors ( $\beta$ - and 2-hydroxypropyl- $\beta-C D$ ) in supramolecular complexes (4-6) showed that in all cases «guest-host» complexes are formed. During the formation of the supramolecular complex (4), changes in proton chemical shifts in the cyclodextrin molecule $\Delta \delta$ occurred to a greater extent in the internal hydrophobic protons $\mathrm{H}-3, \mathrm{H}-$ 5, H-6. The protons H-1, H-2 and H-4 located in the outer hydrophilic surface have insignificant changes.

In molecule (1), the largest changes in the proton spectra are observed for the diethylamine protons $\mathrm{H}-20$, $\mathrm{H}-22, \mathrm{H}-19, \mathrm{H}-21$, and also for the phenylidene protons $\mathrm{H}-14$ and $\mathrm{H}-16$. Screening during complexation requires protons and aromatic pyridine hydrophobic protons $\mathrm{H}-2.6$ and H-3.5. It can be assumed that the higher 
supramolecular interaction of guest and host molecules is carried out using the above-mentioned protons in the process of complex formation (4) (1:2) (Figure 3).

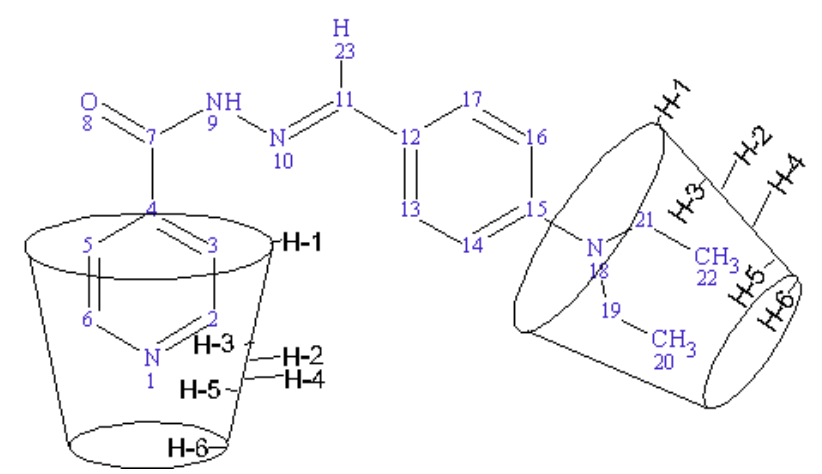

Figure 3. Estimated supramolecular inclusion complexes (4)

The screening of external cyclodextrin protons is probably due to the intermolecular interaction of hydrophilic protons with the external hydroxyl groups of 2-hydroxypropyl- $\beta-\mathrm{CD}$, as well as the possible slight formation of external complexes [19-24]. A significant change in the chemical shifts of the imine proton H-9 is probably due to hydrophilic interaction with its hydroxy groups of the receptor.

The supramolecular self-assembly of the substrate (2) with $\beta$ - and 2-hydroxypropyl- $\beta$-CDs with the formation of supracomplexes (5) and (6) was also accompanied by a change in the internal hydrophobic protons of the CDs and a slight screening of the external protons of the receptor. In molecule (1), the largest changes in proton chemical shifts occurred in the phenyl and pyridine fragments. When using $\beta$-CD-receptor as the receptor, the greatest changes in proton chemical shifts were observed in the protons of the pyridine fragment of the complex (5), while the use of 2-hydroxypropyl- $\beta$-CD in supramolecular self-assembly with substrate 2 leads to the greatest change in the chemical shifts of protons phenyl radical in the supracomplex (6). The proposed models of supramolecular complexes (5) and (6) are similar in structure and are presented in Figure 4.

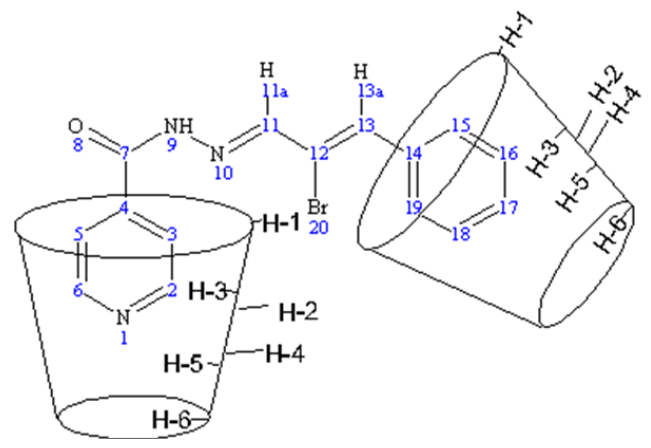

Figure 4. Estimated supramolecular inclusion complexes (5) and (6)

In the ${ }^{1} \mathrm{H}$ NMR spectrum of compound (3), the proton $\mathrm{H} 4$ of the furan fragment appeared as a singleproton doublet at $7.29 \mathrm{ppm}$. with $3 \mathrm{~J} 4.4 \mathrm{~Hz}$. The remaining furan proton $\mathrm{H} 3$ resonated together with the pyridine protons $\mathrm{H} 15.19$ with a three-proton multiplet at 7.76-7.79 ppm. The pyridine protons $\mathrm{N}-16.18$ manifested themselves as a two-proton doublet at $8.77 \mathrm{ppm}$. with $3 \mathrm{~J} 5.6 \mathrm{~Hz}$. The proton $\mathrm{H} 8$ at the unsaturated carbon atom and the amide proton $\mathrm{H} 10$ appeared as single-proton singlets at 8.36 and $12.41 \mathrm{ppm}$. respectively.

In the ${ }^{13} \mathrm{C}$ NMR spectrum of compound (3), the signals of the carbon atoms of the furan fragment appeared at 115.08 (C3), 11.61 (C4), 151.83 (C5) and 152.59 (C2) ppm. The signals of the carbon nuclei of the pyridine ring are observed at 122.07 (C15.19), 140.35 (C14) and 150.99 (C16.18) ppm. The unsaturated carbon atom C8 resonated at $137.20 \mathrm{ppm}$. Chemical shift signal at $162.53 \mathrm{ppm}$ corresponds to the carbon atom C11 of the urea group [28-30].

The structure of compound (3) was also confirmed by the methods of two-dimensional NMR spectroscopy COSY $\left({ }^{1} \mathrm{H}-1 \mathrm{H}\right)$ and $\mathrm{HMQC}\left({ }^{1} \mathrm{H}-{ }^{13} \mathrm{C}\right)$, which allows one to establish spin-spin interactions of a homo- and heteronuclear nature. The observed correlations in the molecule are shown in Figure 5. In the ${ }^{1} \mathrm{H}-{ }^{1} \mathrm{H}$ COSY 
spectrum of compound (3), spin-spin correlations are observed through three bonds of the neighboring methine-methine protons of the $\mathrm{H} 4-\mathrm{H} 3$ furan ring (cross-peak coordinates, ppm: 7, 28, 7.76 and 7.76, 7.28) and aromatic protons H15.19-H16.18 (coordinates of cross peaks, ppm: 7.78, 8.76 and 8.7, 7.77) pyridine ring. Heteronuclear interactions of protons with carbon atoms through one bond were established using ${ }^{1} \mathrm{H}-{ }^{13} \mathrm{C}$ HMQC spectroscopy (Figure 5) for all pairs present in the compound: H4-C4 (7.27, 116.62), H3-C3 (7.75, 115, 04), H15.19-C15.19 (7.76, 122.10), H8-C8 (8.35, 137.21), H16.18-C16.1 (8.77, 150.96).

As a result of the studies, the supramolecular complexes (7) and (8) were first obtained on the basis of functionally substituted $\mathrm{N}$ '- ((5-nitro-furan-2-yl) methylene) isonicotinohydrazide with cyclodextrins $(\beta-\mathrm{CD}$ and 2-hydroxypropyl- $\beta$ - CD).
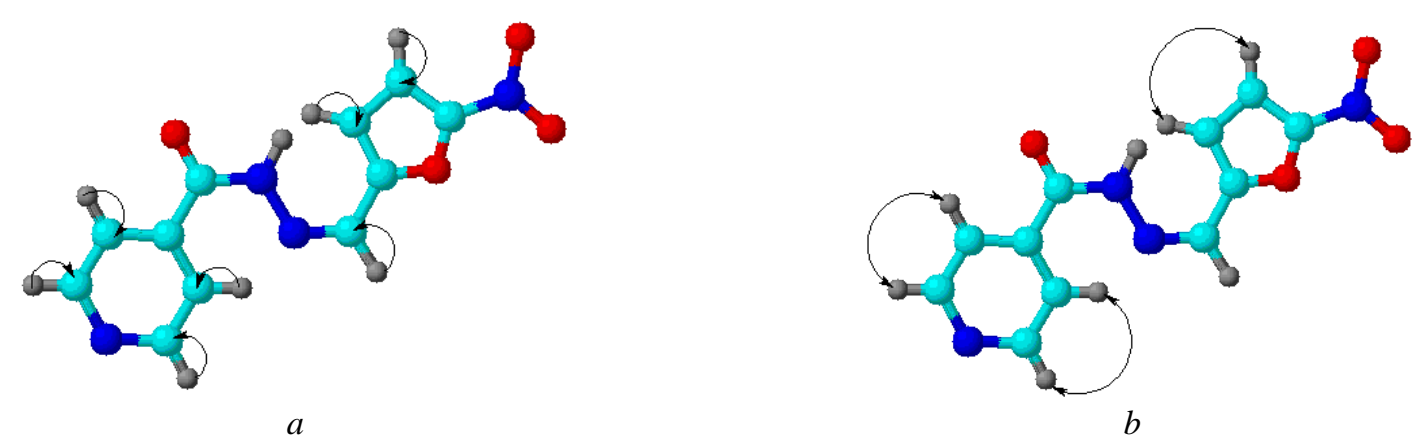

Figure 5. Correlation scheme in the spectra of HMQC $(a)$ and COZY $(b)$ compounds (3)

The study of supracomplexes with $\beta$-CD (7) and 2-hydroxypropyl- $\beta$-CD (8) showed that in both cases substrate inclusion complexes (3) with a cyclodextrin receptor cavity are formed. The greatest change in the chemical shifts of protons in the process of formation of supra-molecular complexes occurs with the internal protons H-3 and H-5 of the cyclodextrin cavity. In the formation of a substrate inclusion complex (3) with $\beta-\mathrm{CD}$, the greatest change in chemical shifts occurs with protons of the pyridine fragment. In the case of using $2-\mathrm{HP}-\beta-\mathrm{CD}$, a proton of the furan cycle undergoes a greater change in chemical shifts. This indicates the entry of the substrate molecule into the cyclodextrin cavity by the pyridine fragment in the case of using $\beta$-CD-Na (Scheme 1) and the furanose cycle in the case of 2-HP- $\beta$-CD (Scheme 2).

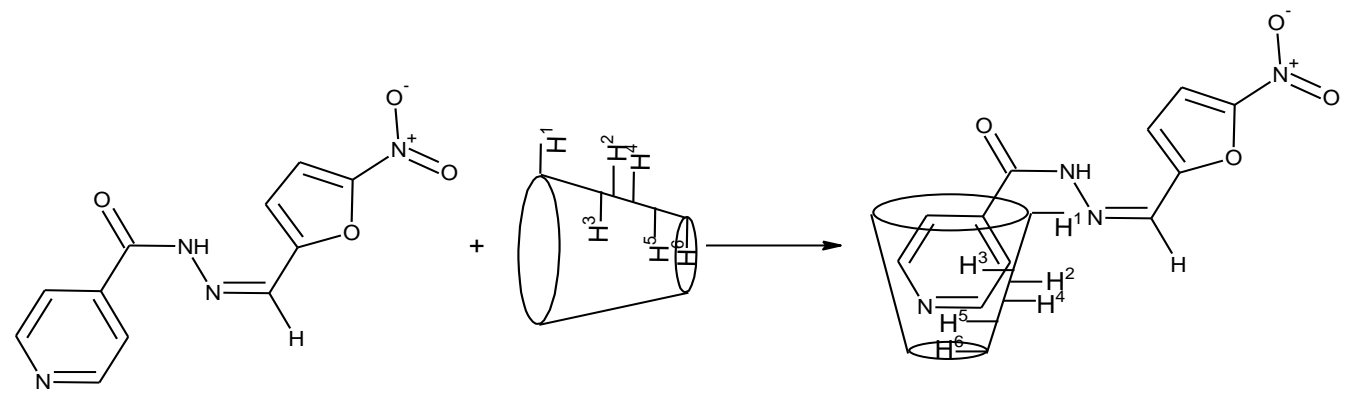

(3)

(7)

Scheme 1. The formation of supramolecular complex (7)

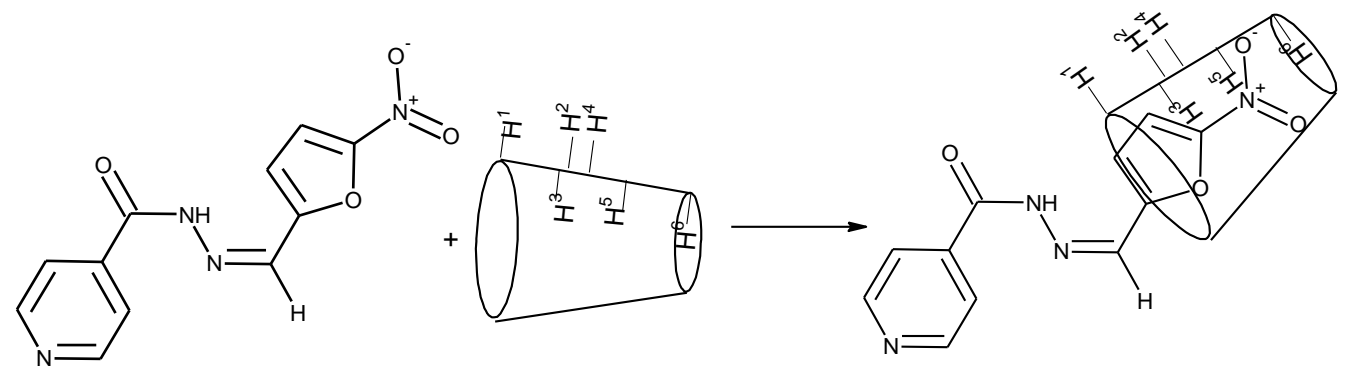

(3)

(8)

Scheme 2. Formation of a supramolecular complex (8) 
The ${ }^{1} \mathrm{H}$ and ${ }^{13} \mathrm{C}$ NMR spectra of compound (3) in the free state and in the composition of supramolecular complexes (7) and (8) obtained in DMSO- $\mathrm{d}_{6}$ are presented in Tables 5 and 6.

Chemical shifts of ${ }^{1} \mathrm{H}$ and ${ }^{13} \mathrm{C}$ nuclei of the substrate (3)

in the free state $\left(\delta_{0}\right)$ and in the complexes $(7)\left(\delta_{1}\right),(8)\left(\delta_{2}\right)$

\begin{tabular}{|c|c|c|c|c|c|c|c|}
\hline \multirow{2}{*}{$\begin{array}{c}\text { Atom } \\
\text { number }\end{array}$} & \multirow{2}{*}{ Group } & ${ }^{13} \mathrm{C}$ & \multicolumn{5}{|c|}{${ }^{1} \mathrm{H}$} \\
\cline { 3 - 7 } & $\delta_{0}$ & $\delta_{0}$ & $\delta_{1}$ & $\Delta \delta_{1}=\delta_{1}-\delta_{0}$ & $\delta_{2}$ & $\Delta \delta_{2}=\delta_{2}-\delta_{0}$ \\
\hline 2 & $>\mathrm{C}<$ & 152.59 & & & & & \\
\hline 3 & $\mathrm{CH}$ & 115.08 & 7.78 & 7.77 & -0.01 & 7.90 & 0.12 \\
\hline 4 & $\mathrm{CH}$ & 140.35 & 7.29 & 7.28 & -0.01 & 7.26 & -0.03 \\
\hline 5 & $>\mathrm{C}<$ & 151.83 & & & & & \\
\hline 8 & $=\mathrm{CH}$ & 137.20 & 8.36 & 8.35 & -0.01 & 8.38 & 0.02 \\
\hline 10 & $\mathrm{NH}$ & & 12.41 & 12.41 & 0 & & \\
\hline 11 & $>\mathrm{CO}$ & 162.53 & & & & & \\
\hline 14 & $>\mathrm{C}<$ & 140.35 & & & & & \\
\hline 15 & $\mathrm{CH}$ & 122.07 & 7.78 & 7.75 & -0.03 & 7.78 & 0 \\
\hline 16 & $\mathrm{CH}$ & 150.99 & 8.77 & 8.75 & -0.02 & 8.75 & -0.02 \\
\hline 18 & $\mathrm{CH}$ & 150.99 & 8.77 & 8.75 & -0.02 & 8.75 & -0.02 \\
\hline 19 & $\mathrm{CH}$ & 122.07 & 7.78 & 7.75 & -0.03 & 7.78 & 0 \\
\hline
\end{tabular}

A comparison of the integral intensities of ${ }^{1} \mathrm{H}$ NMR signals of molecule (3) with $\beta$ - and 2-hydroxypropyl$\beta$-CD in supracomplexes showed that in both cases complexes of the composition of one substrate molecule per one receptor molecule are formed. The resulting products form a mixture capable of dissolving in water or forming stable aqueous dispersions.

To obtain inclusion complexes of functionally substituted N'-((5-nitrofuran-2-yl)methylene) isonicotinohydrazide (3) with $\beta$-cyclodextrins, we chose the coprecipitation method, since this method is simple and easy to implement.

Table 6

Chemical shifts of ${ }^{1} \mathrm{H}$ nuclei of $\beta$ - and 2-hydroxypropyl- $\beta$-CD in the free state $\left(\delta_{0}\right)$ and as part of complexes $(7)\left(\delta_{1}\right)$ and $(8)\left(\delta_{2}\right)$, ppm

\begin{tabular}{|c|c|c|c|c|c|c|}
\hline \multirow{2}{*}{ Atom number } & \multicolumn{3}{|c|}{$\beta-C D$} & \multicolumn{3}{|c|}{$2-\mathrm{HP}-\beta-\mathrm{CD}$} \\
\hline & $\delta_{0}$ & $\delta_{1}$ & $\Delta \delta_{1}=\delta_{1}-\delta_{0}$ & $\delta_{0}$ & $\delta_{2}$ & $\Delta \delta_{2}=\delta_{2}-\delta_{0}$ \\
\hline 1 & 4.77 & 4.77 & 0 & 4.79 & 4.79 & 0 \\
\hline 2 & 3.26 & 3.25 & -0.01 & 3.26 & 3.27 & 0.01 \\
\hline 3 & 3.58 & 3.52 & -0.06 & 3.70 & 3.73 & 0.03 \\
\hline 4 & 3.28 & 3.28 & 0 & 3.26 & 3.27 & 0.01 \\
\hline 5 & 3.50 & 3.58 & 0.08 & 3.54 & 3.50 & -0.04 \\
\hline 6 & 3.58 & 3.55 & -0.03 & 3.56 & 3.58 & 0.02 \\
\hline 7 & & & & 3.26 & 3.26 & 0 \\
\hline 8 & & & & 3.70 & 3.70 & 0 \\
\hline 9 & & & & 0.98 & 0.96 & -0.02 \\
\hline
\end{tabular}

In order to study the biological activity of the obtained supramolecular inclusion complexes (4-6), we evaluated their antiradical effect against 2,2-diphenyl-1-picryl hydrazide (DPPH). The antiradical effect of the presented samples was investigated in relation to the radical 2,2-diphenyl-1-picryl hydrazide (DPPH•).

For the initial assessment of the antiradical activity of the studied samples in the test with the DPPH radical, a methanol solution of DPPH $(100 \mu \mathrm{M})$ was used. To select substances with a pronounced anti-radical activity, $2 \mathrm{ml}$ of $100 \mu \mathrm{M}$ DPPH methanol solution was mixed with $20 \mu \mathrm{l}$ of the test object dissolved in DMSO at a concentration of $5 \mathrm{mM}$. Thus, the final concentration of the test substance in the reaction mixture was 50 $\mu \mathrm{M}$. 10 minutes after adding the solution of the test compound to the solution of the DPPH radical, we measure the decrease in optical density at $515 \mathrm{~nm}$. For substances capable of reducing the optical density by more than $30 \%$, a test was carried out for interaction with the DPPH radical in the final concentrations of the investigated substances $100,75,50,25,20,10$, and $5 \mu \mathrm{M}$. After that, the concentration of the test substance was determined, 
capable of $50 \%$ reduction in optical density $-\mathrm{IC}_{50}(\mathrm{DPPH})$ (Table 7). In a control in a $100 \mu \mathrm{M}$ DPPH solution, $20 \mu \mathrm{l}$ of a DMSO solvent was added.

The optical density of a solution of $100 \mu \mathrm{M}$ DPPH radical after 10-minute incubation with the test substance in a final concentration of $50 \mu \mathrm{M}$

\begin{tabular}{|c|c|c|c|}
\hline № & Connection cipher & $\begin{array}{c}\text { Optical } \\
\text { density }\end{array}$ & $\begin{array}{c}\text { The magnitude of the decrease in optical density } \\
\text { of the initial solution of the DPPH radical, in \% of control }\end{array}$ \\
\hline 1 & $(4)$ & 0.535 & 52.3 \\
\hline 2 & $(5)$ & 1.094 & 2.5 \\
\hline 3 & $(6)$ & 1.058 & 5.7 \\
\hline 4 & $\begin{array}{c}\text { Control (DPPH solution } \\
\text { without test sample) }\end{array}$ & 1.122 & - \\
\hline
\end{tabular}

From Table 7 we see that compound (4) in a final concentration of $50 \mu \mathrm{M}$ reduces the optical density of the initial solution of the DPPH radical by $52.3 \%$, and therefore, is promising for further studies. The remaining compounds did not show pronounced antiradical activity under the conditions of this test system.

In the second series of experiments, we studied the ability of compound (4) and of ascorbic acid at various concentrations (from 5.0 to $100 \mu \mathrm{M}$ ) to interact with the DPPH radical (Tables 8, 9). Using the calibration curves, we determined the concentrations of compound (4) and of ascorbic acid, capable of $50 \%$ reduction in the optical density of a $100 \mu \mathrm{M}$ solution of the DPPH radical. For compound (4), the $\mathrm{IC}_{50}(\mathrm{DPPH})$ was found to be $46.4 \mu \mathrm{m}$. For ascorbic acid, the $\mathrm{IC}_{50}(\mathrm{DPPH})$ was found to be $21.14 \mu \mathrm{M}$.

Table 8

The optical density of a solution of $100 \mu \mathrm{M}$ DPPH radical after a 10-minute incubation with compound (4) in final concentrations in the reaction mixture of $100,75,50,25,20,10$ and $5 \mu M$

\begin{tabular}{|c|c|c|}
\hline № & $\begin{array}{c}\text { The final concentration of compound (4) } \\
\text { in the reaction mixture, } \mu \mathrm{M}\end{array}$ & $\begin{array}{c}\text { Optical } \\
\text { density }\end{array}$ \\
\hline 1 & 100 & 0.079 \\
\hline 2 & 75 & 0.275 \\
\hline 3 & 50 & 0.491 \\
\hline 4 & 25 & 0.723 \\
\hline 5 & 20 & 0.798 \\
\hline 6 & 10 & 0.907 \\
\hline 7 & 5 & 0.963 \\
\hline \multicolumn{2}{|l}{} \\
\hline
\end{tabular}

Table 9

The optical density of a solution of $100 \mu \mathrm{M}$ DPPH radical after a 10-minute incubation with ascorbic acid in final concentrations in the reaction mixture of $25,20,10$ and $5 \mu M$

\begin{tabular}{|c|c|c|}
\hline № & $\begin{array}{c}\text { The final concentration of ascorbic acid } \\
\text { in the reaction mixture, } \mu \mathrm{M}\end{array}$ & $\begin{array}{c}\text { Optical } \\
\text { density }\end{array}$ \\
\hline 1 & 25 & 0.429 \\
\hline 2 & 20 & 0.545 \\
\hline 3 & 10 & 0.792 \\
\hline 4 & 5 & 0.914 \\
\hline & Control (DPPH solution without test sample) & 1.042 \\
\hline
\end{tabular}

\section{Conclusions}

Thus, supramolecular complexes based on functionally substituted N-benzylidene and allylideneisonicotinohydrazide with cyclodextrins ( $\beta-C D, 2$-hydroxypropyl- $\beta-C D)$ were obtained and their structures were studied by NMR spectroscopy. It was shown that the products obtained form a mixture capable of dissolving in 
water or forming stable aqueous dispersions. The antiradical effect of the synthesized supramolecular inclusion complexes with respect to the DPPH radical was evaluated. The antiradical activity in the conditions of this test system was shown by the sample (4). The concentration was determined, capable of $50 \%$ reduction in the optical density of $100 \mu \mathrm{M}$ solution of the $\mathrm{DPPH}$ radical. For compound (4), the $\mathrm{IC}_{50}(\mathrm{DPPH})$ was $46.4 \mu \mathrm{M}$.

According to our data, $\mathrm{IC}_{50}(\mathrm{DPPH})(\mu \mathrm{M})$ for the reference sample, in this case, for ascorbic acid was $21.1 \mu \mathrm{M}$. The activity of the sample of compound (4), for which the $\mathrm{IC}_{50}(\mathrm{DPPH})$ was equal to $46.4 \mu \mathrm{M}$ and is inferior to the reference sample of ascorbic acid.

According to the literature [18-26], the $\mathrm{IC}_{50}(\mathrm{DPPH})(\mu \mathrm{M})$ for ascorbic acid is 27 , for glutathione is 49 , for hydroquinone is 27 , for trolled is 28 , for $\alpha$-tocopherol is 28 . Thus, the activity of the compound (4) is comparable to the activity of the glutathione known antioxidant.

\section{References}

1 Labhasetnar V. Biomedical Applications of Nanotechnology / V. Labhasetnar, D.L. Leslie-Pelecky. — Publ. J. Wiley and sons, New Jersy, 2007. - $251 \mathrm{p}$.

2 Mashkevich B.O. Drug Delivery Researches Advances / B.O. Mashkevich. — Nova Sience Publ, 2008. — 259 p.

3 Villers M.M. Nanothechnology in Drug Delivery / Villers M.M., Aramwit P., Kwon G.S. — AAPS PRESS, 2009. — 662 p.

4 Szejtli J. () Introduction and general overview of cyclodextrin chemistry / J. Szejtli // Chemical Reviews. - 1998. - Vol. 98 , No. 5. - P. 1743-1754. DOI: $10.1021 / \mathrm{cr} 970022 \mathrm{c}$.

5 Heise H.M. Infrared spectroscopy and Raman spectroscopy of cyclodextrin derivatives and their ferrocene inclusion complexes / H.M. Heise, R. Kuckuk, A. Bereck, D. Riegel // Vibrational Spectroscopy. - 2010. — Vol. 25, No. 1. - P. 19-23. DOI: 10.1016/j.vibspec.2010.01.012.

6 Larsen K.L. Large cyclodextrins / K.L. Larsen // Journal of Inclusion Phenomena and Macrocyclic Chemistry. — 2002. Vol. 43, No. 1. - P. 1-13. DOI: 10.1023/A:1020494503684.

7 Endo T. Large ring cyclodextrins - recent progress / T. Endo, H. Ueda // FABAD Journal of Pharmaceutical Sciences. 2004. - Vol. 29, No. 1. - P. 27-38.

8 Endo T. Large ring cyclodextrins: recent progress / T. Endo, H. Ueda // ChemInform. - 2006. - P. 37-38. DOI: 0.1002/chin.200638261.

9 Endo T. Large-ring cyclodextrins / T. Endo // Trends in Glycoscience and Glycotechnology. — 2011. Vol. 23, No. 130. — P. 79-92. DOI: 10.4052/tigg.23.79.

10 Loftsson T. Cyclodextrins as pharmaceutical excipients / T. Loftsson, M.E. Brewster // Pharmaceutical Tech. Europe. — 1997. - Vol. 9. - P. 26-35.

11 Jug M. Analysis of triclosan inclusion complexes with $\beta$-cyclodextrin and its water-soluble polymeric derivative / M. Jug, I. Kosalec, F. Maestrelli, P. Mura // Journal of Pharmaceutical and Biomedical Analysis. - 2011. — Vol. 54, No. 5. - P. 1030-1039. DOI: $10.1016 / \mathrm{j}$.jpba.2010.12.009.

12 Zheng M. Enzymatic synthesis and analysis of largering cyclodextrins / M. Zheng, T. Endo, W. Zimmermann // Australian Journal of Chemistry. — 2002. — Vol. 55. — P. 39-48. DOI: 10.1071/CH01189.

13 Schneider H.-J. NMR Studies of Cyclodextrins and Cyclodextrin Complexes / H.-J. Schneider, F. Hacket, V. Rüdiger, H. Ikeda // Chem. Rev. - 1998. - Vol. 98, No. 5. - P. 1755-1785. DOI: 10.1021/cr970019t.

14 Chernykh E.V. Supramolecular Complexes Based on Cyclodextrins / E.V. Chernykh, S.B. Brichkin // High Energy Chemistry. - 2010. - Vol. 44, No. 2. - P. 83-100. DOI: 10.1134/S0018143910020013.

15 Rasheed A. Cyclodextrins as Drug Carrier Molecule. A Review / A. Rasheed, A.S.K. Kumar, V.V. Sravanthi // Sci. Pharm. 2008. — Vol. 76, No. 4. - P. 567-598. DOI: 10.3797/scipharm.0808-05.

16 Nalwa H.S. Cancer Nanotechnology - Nanomaterials for Cancer Diagnosis and Therapy. / H.S. Nalwa, T. Webster. - Amer. Sci. Publ., 2007. - 355 p.

17 Rasheed A. Cyclodextrins as Drug Carrier Molecule. A Review / A. Rasheed, A.S.K. Kumar, V.V. Sravanthi // Sci. Pharm. 2008. Vol. 76, No. 4. - P. 567-598. DOI: 10.3797/scipharm.0808-05.

18 Wiseman B. Isonicotinic acid hydrazide conversion to Isonicotinyl-NAD by catalase-peroxidases / B. Wiseman, X. Carpena, M. Feliz, L.J. Donald, M. Pons, I. Fita, P.C. Loewen // J. Biol. Chem. - 2010. — Vol. 285, No. 34. — P. 26662-26673. DOI: 10.1074/jbc.M110.139428.

19 Judge V. Isonicotinic acid hydrazide derivatives: Synthesis, antimicrobial activity, and QSAR studies / V. Judge, B. Narasimhan, M. Ahuja, J. Balzarini et al. // Med. Chem. Res. — 2012. — Vol. 21. — P. 1451-1470 pp. DOI 10.1007/s00044-0119662-9.

20 Glavind J. Antioxidants in animal tissue / J. Glavind // Acta Chem Scand. 1963. — Vol. 13. — P. 1635-1640. DOI 10.3891 / acta.chem.scand. Volume (17), P.1635.

21 Sun G.X. Design, synthesis, biological activities and 3D-QSAR of new N,N-diacylhydrazines containing 2,4-dichlorophenoxy moieties / G.X. Sun, Z.H. Sun, M.Y. Yang, X.H. Liu, Y. Ma, Y.Y. Wei // Molecules. — 2013. — Vol. 18, No. 12. — P. $14876-14891$.

22 Liu X.H. Synthesis, crystal structure, herbicidal activities and 3D-QSAR study of some novel 1,2,4-triazolo[4,3-a]pyridine derivatives / X.H. Liu, X.Y. Xu, C.X. Tan, J.Q. Weng, J.H. Xin, J. Chen // Pest Management Science. — 2015. — Vol. 72, № 2. — P. 292-301.

23 Zhang L.J. Synthesis and antifungal activity of 1,3,4-thiadiazole derivatives containing pyridine group / L.J. Zhang, M.Y. Yang, Z.H. Sun et al. // Letters in Drug Design \& Discovery. — 2014. — Vol. 11, No. 9. — P. 1107-1111. 
24 Plattner S. Studying the reducing potencies of antioxidants with the electrochemistry inherently present in electrospray ionization-mass spectrometry / S. Plattner et al. // Analytical and Bioanalytical Chemistry. — 2014. — Vol. 406, No. 1. - P. $213-224$.

25 Dodziuk H. Cyclodextrins and Their Complexes. Chemistry, Analytical Methods, Applications / H. Dodziuk. - Warsaw: Willey-VCH, Weinheim, 2006. - 504 p.

26 Marques C.H.M. Studies of cyclodextrin inclusion complexes. I. The salbutamol cyclodextrin complex as studied by phase solubility and DSC / C.H.M. Marques, J. Hadgraft, I.W. Kellaway // International Journal of Pharmaceutics. — 1990. — Vol. 63, No. 3. - P. 259-266.

27 Xiang T.X. Inclusion complexes of purine nucleosides with cyclodextrins: II. Investigation of inclusion complex geometry and cavity microenvironment / T.X. Xiang, B.D. Anderson // International Journal of Pharmaceutics. — 1990. — Vol. 59, No. 1. — P. 4555 .

28 Beni S. Cyclodextrin/imatinib complexation: binding mode and charge dependent stabilities / S. Beni, Z. Szakács, O. Csernák, L. Barcza, B. Noszál // European Journal of Pharmaceutical Sciences. — 2007. - Vol. 30, No. 2. — P. 167-174.

29 Nurkenov O.A. Complexes of inclusion of functionally-substituted hydrazons of isonicotinicasid with cyclodexstrines and their antiradical activity / O.A. Nurkenov, S.D. Fazylov, A.Zh. Issaeva, T.M. Seilkhanov, T.S. Zhivotova, Z.T. Shulgau, Zh.M. Kozhina // News of the NAS of the Republic of Kazakhstan. Series Chem. and Tech. - 2018. - Vol. 6, No. 432. - P. 57-66.

30 Nurkenov O.A. Synthesis, Structure and Anti-radical Activity of 6-methyl-4-oxo-4H-chromen-3-acylhydrazones / O.A. Nurkenov, M.K. Ibraev, T.M. Seilkhanov, Z.T. Shulgau, S.D. Fazylov, A.T. Takibayeva // News of the NAS of the Republic of Kazakhstan. Series Chem. and Tech. - 2019. - Vol. 4. - P. 25-31.

31 Tazhbaev E.M. Enthalpy of swelling of crosslinked copolymers of acrylic amid acid beta-vinyloxyethylamide in water and ethanol / E.M. Tazhbaev, E.S. Mustafin, M.Zh. Burkeev, B.K. Kasenov // Russian journal of physical chemistry. — 2006. — Vol. 80, No. 8. - P. 1300-1304.

\author{
С.Д. Фазылов, О.А. Нүркенов, А.Ж. Мукашева, \\ Т.М. Сейлханов, 3.Т. Шульгау, Ә.М. Жанжұман \\ Функционалды ауысқан N-бензилиден- және \\ аллилиденизоникотингидразидтердің олигосахаридтермен \\ супрамолекулярлы қосылу кешендері және олардың қасиеттері
}

\begin{abstract}
$\mathrm{N}$-бензилден- және аллилиденизоникотингидразидтердің циклдік олигосахаридтермен ( $\beta$ - және 2-гидроксипропил- $\beta$-циклодекстриндермен) қосылудың супрамолекулярлық кешендерінің синтезі мен құрылымдық ерекшеліктерін зерттеу нәтижелері ұсынылған. Алынған супрамолекулярлы қосу кешендерінің құрылымы ЯМР бір өлшемді ${ }^{1} \mathrm{H},{ }^{13} \mathrm{C}$ және қос өлшемді COSY $\left({ }^{1} \mathrm{H}-{ }^{-1} \mathrm{H}\right), \mathrm{HMQC}\left({ }^{1} \mathrm{H}-{ }^{13} \mathrm{C}\right)$ және TOCSY $\left({ }^{1} \mathrm{H}-\right.$ $\left.{ }^{1} \mathrm{H}\right)$ спектроскопия әдістерін қолдана отырып зерттелген. Супрамолекулярлы қосу кешендерінің түзілуі субстрат атомдары мен рецепторлардың ЯМР химиялық ығысуының өзгеру негізінде белгіленген. Спектрлік деректерді талдау негізінде алынған супрамолекулярлық қосылым кешендерінің болжамды схемалары берілген. Зерттелетін гидразинді субстраттардың циклодекстриндермен өзара әрекеттесуі кезінде субстрат молекуласының рецептордың ішкі куысына енуімен 1:1 және 1:2 кешендері түзілетіні анықталған. Алынған өнімдер суда еруге немесе тұрақты су дисперсияларын құруға қабілетті. 2,2-дифенил-1-пикрил-гидразид-радикалға қатысты синтезделген супрамолекулярлы қосу кешендерінің антирадикалды әсері бағаланды. Осы тест-жүйе жағдайында антирадикалды белсенділікті тек N-(диэтиламино)бензилиденизоникотиногидразид супрамолекулярлық кешені ғана көрсетті.
\end{abstract}

Кілт сөздер: олигосахаридтер, гидразондар, циклодекстрин, қосылу кешендері, ЯМР спектроскопиясы, субстрат.

С.Д. Фазылов, О.А. Нуркенов, А.Ж. Мукашева,

Т.М. Сейлханов, 3.Т. Шульгау, А.М. Жанжуман

\title{
Супрамолекулярные комплексы включения функционально-замещенных $\mathrm{N}$-бензилиден- и аллилиденизоникотиногидразидов с олигосахаридами и их свойства
}

\begin{abstract}
Рассмотрены результаты изучения синтеза и структурных особенностей супрамолекулярных комплексов включения $\mathrm{N}$-бензилиден- и аллилиденизоникотиногидразидов с циклическими олигосахаридами (с $\beta$ - и 2-гидроксипропил- $\beta$-циклодекстринами). Строение полученных супрамолекулярных комплексов включения изучено с применением методов ЯМР одномерной ${ }^{1} \mathrm{H},{ }^{13} \mathrm{C}$ и DEPT и двумерной спектроскопии COSY $\left({ }^{1} \mathrm{H}-{ }^{1} \mathrm{H}\right)$, HMQC $\left({ }^{1} \mathrm{H}^{-13} \mathrm{C}\right)$ и TOCSY $\left({ }^{1} \mathrm{H}-{ }^{1} \mathrm{H}\right)$. Образование супрамолекулярных комплексов включения выявлено на основе изменений химических сдвигов ЯМР атомов субстрата и рецептора. На основании анализа спектральных данных представлены предполагаемые схемы полученных супрамолекулярных комплексов включения. Установлено, что при взаимодействии изучаемых гидразоновых
\end{abstract}


субстратов с циклодекстринами образуются комплексы включения 1:1 и 1:2 с вхождением молекулы субстрата во внутреннюю полость рецептора. Полученные продукты способны растворяться в воде или образовывать устойчивые водные дисперсии. Оценено антирадикальное действие синтезированных супрамолекулярных комплексов включения в отношении 2,2-дифенил-1-пикрил-гидразид-радикала. Антирадикальную активность в условиях данной тест-системы проявил только супрамолекулярный комплекс N-(диэтиламино)бензилиденизоникотиногидразида.

Ключевые слова: олигосахариды, гидразоны, циклодекстрин, комплексы включения, спектроскопия ЯМР, субстрат. 